\title{
A model system for the analysis of gene exclusion: cystic fibrosis and chromosome 19
}

\author{
BRANDON WAINWRIGHT, MARTIN FARRALL, EILA WATSON, AND \\ ROBERT WILLIAMSON
}

From the Department of Biochemistry, St Mary's Hospital Medical School, University of London, London W2 IPG.

SUMMARY We have used multilocus analysis to exclude the cystic fibrosis locus from six polymorphic DNA markers covering most of chromosome 19. A substantial increase in the confidence for exclusion was obtained using the computer programme LINKAGE compared to analysis of pairwise lod scores. A structured approach to the analysis of linkage to autosomal recessive inherited diseases where the biochemical defect is not known is described.

Cystic fibrosis (CF) is the most common genetic disease in North European populations, with an incidence of 1 in 2000 live births in the United Kingdom. The biochemical basis of the mutation in $\mathrm{CF}$ is not known, although membrane transport phenomena associated with the disease have recently been described. ${ }^{12}$ Evidence from segregation analyses has confirmed that the inheritance of $\mathrm{CF}$ is consistent with its being a recessive defect caused by a mutation at a single autosomal locus. ${ }^{3}$

The use of DNA probes for the analysis of genetic disease allows the determination of linkage between a restriction fragment length polymorphism (RFLP) and a disease locus even when the biochemical defect is unknown. This approach has already been used successfully by us to analyse sex linked genetic diseases such as Duchenne muscular dystrophy, ${ }^{4}$ as well as to study previously unassigned autosomal dominant diseases such as Huntington's disease. ${ }^{5}$

There were, until recently, few clues as to the chromosomal localisation of the CF locus $(C F)$. Mayo et $a l^{6}$ suggested that $C F$ might be located on chromosome 4 , based on data from cell hybrids expressing a ciliary dyskinesis factor. We have shown that the mutation causing $C F$ is unlikely to be on chromosome 4 by exclusion mapping with several DNA and protein markers. ${ }^{7}$ Two different families have been reported showing chromosomal anomalies, one of which suggested that the CF mutation mapped to chromosome $5 \mathrm{p},{ }^{8}$ and the other suggested

Received for publication 6 January 1986. Aocepted for publication 18 February 1986. chromosome 13q34. ${ }^{9}$ We investigated the latter family initially by mapping the gene for factor $X$ to $13 \mathrm{q} 34$ by gene dosage experiments and then excluded $C F$ from linkage to factor $X .{ }^{1011}$ We have also demonstrated that certain candidate genes, such as complement component 3 , which had been proposed as the locus of the $C F$ mutation, do not segregate with the disease. ${ }^{12}$

Since this research was completed, Eiberg et $a l^{13}$ have reported linkage between $C F$ and $P O N$ (paraoxonase) and several groups, including our own, have reported that the mutation causing cystic fibrosis is located on the long arm of chromosome 7 and shows linkage to $3 \cdot 11$ and $T C R B,{ }^{14}$ to $C O L 1 A 2,{ }^{15}$ to $M E T{ }^{16}$ and to DOCR 1-917.17

Although linkage between markers and $C F$ has now been shown, our data for chromosome 19 illustrate the use of multipoint computer analyses which analyse multiple linked markers along a single chromosome to maximise data from the few informative families that can be obtained. It is therefore a paradigm for any single gene autosomal recessive disease where the biochemical defect is unknown. Multipoint linkage is of particular value as it usefully extends the exclusion regions between the markers to exclude most of the chromosome.

\section{Materials and methods}

GENE PROBES LOCATED ON CHROMOSOME 19 The cloned DNA sequences used in this study are listed in table 1 together with regional assignments of the markers and details of the RFLP defined by 
TABLE 1 Polymorphisms used in this study.

\begin{tabular}{|c|c|c|c|c|c|}
\hline Marker & $\begin{array}{l}\text { Regional } \\
\text { assignment }\end{array}$ & $\begin{array}{l}\text { RFLP } \\
\text { enzyme }\end{array}$ & $\begin{array}{l}\text { No of } \\
\text { alleles }\end{array}$ & $\begin{array}{l}\text { Frequency } \\
\text { of } \\
\text { rare allele }\end{array}$ & References \\
\hline LDLR & $\mathrm{p} 13.2 \rightarrow \mathrm{p} 13.1$ & Prull & 2 & 0.27 & 26 \\
\hline ( 3 & $\mathrm{pl} 3.3 \rightarrow \mathrm{pl} 3.2$ & SivI & 2 & 0.39 & 12 \\
\hline APOC 2 & $\operatorname{ccn} \rightarrow q 13.2$ & $T a y)$ & 2 & 0.40 & 27 \\
\hline D19S9 & $\mathrm{pl} 3.2 \rightarrow \mathrm{pl} 3.2$ & EcoRl & 2 & 0.19 & 21 \\
\hline CYP1 & $q 13 \cdot 1 \rightarrow q 13.3$ & Sist & 2 & 0.47 & 28 \\
\hline D19S6 & q13.3 $\rightarrow$ qter & Apal & 2 & 0.48 & 29 \\
\hline
\end{tabular}

each clone. A cDNA encoding the $\mathrm{LDL}$ receptor gene was kindly provided by $\operatorname{Dr} \mathrm{D}$ Russell. The gene for complement 3 was obtained from Dr G Fey, ${ }^{18}$ the cDNA clone for apolipoprotein C2 (APOC2) was isolated in this laboratory, ${ }^{19}$ and the cytochrome p450 cDNA recombinant was provided by $\mathrm{Dr} E$ Shepherd.20 Random probes D19S9 and D19S6 were provided by Drs $D S^{2} w^{21}$ and $R$ Bartlett respectively.

CYSTIC FIBROSIS FAMILIES

Twelve European families with at least three affected children and up to four unaffected sibs and two families with two affected children and two normal sibs were used in this study. Blood was collected from all children and parents and DNA prepared by standard methods. ${ }^{22}$

\section{HYBRIDISATION ANALYSIS}

DNA $5 \mu \mathrm{g}$ from each family member was digested with the appropriate restriction enzyme according to the manufacturer's instructions (BRL Ltd, Irvine, Scotland), fractionated by electrophoresis on $0.8 \%$ agarose, and transferred to Zetapore membranes (AMF Cuno) as described by Maniatis et al. ${ }^{\mathbf{2 3}}$ Hybridisation and autoradiography were carried out as described previously. ${ }^{24}$

LIN K A G E ANALYSIS

Pairwise lod scores were calculated using the LIPED computer programme adapted by $\mathrm{Ott}^{25}$ for use with microcomputers. The allele frequencies used are given in table 1 . The multipoint linkage computer package LINKAGE ${ }^{30}$ was used to test for linkage to cystic fibrosis at locations within a fixed map of known linked markers, as discussed by Farrall et $a^{3} .^{31}$ The order of loci $L D L R-C 3-A P O C 2-C Y P 1-$ $D$ 19S6 was deduced from physical assignments, two point lod scores, and multipoint calculations. ${ }^{29} 32$ There were insufficient data to place D19S9 accurately within the other markers. Estimates of recombination fractions between markers were taken from HGM8 and our own multipoint estimates. Each map distance is calculated from the upper limit $(95 \%$ confidence interval) of the recombination fraction estimate by using Haldane's mapping function. ${ }^{33}$ The use of this mapping function effectively disregards the influence of interference in subsequent analyses. By using the upper limits of the recombination fraction estimates and ignoring interference, the estimates of exclusion are cautious. Multipoint likelihoods may be conveniently presented as a location map, in the manner of Lathrop et al. ${ }^{30}$ For pairwise analyses, a lod score of -2.0 calculated for combined sexes was considered to exclude linkage significantly between $C F$ and each marker at the relevant recombination fraction. For multipoint calculations, a location score of $\mathbf{- 9 \cdot 2}$ (lod equivalent $=-2 \cdot 0$ ) for $C F$ within the fixed map of markers was similarly considered to exclude linkage.

\section{Results}

Table 2 shows the pairwise lod scores obtained for each probe and $C F$. Fig 1 shows the physical location of the markers used in this study. Fig 2 shows the multipoint likelihood map for CF within the linked markers $L D L R, C 3, A P O C 2$, and $C Y P 1$. From the pairwise results we can exclude $C F$ from moderate linkage to $L D L R$ and $C 3$, and tight linkage to APOC2, D19S9, CYP1, and D19S6. Multipoinf analysis shows that the exclusion regions may be extended between $L D L R, C 3, A P O C 2$, and $C Y P Y$ O The total excluded genetic length for multipoint analysis is 88 centiMorgans (cM) (LDLR-C3APOC2-CYP-1-D19S6). An estimate of the total

TABLE 2 Lod scores at selected recombination fractions between $C F$ and six chromosome 19 markers.

\begin{tabular}{|c|c|c|c|c|c|c|c|}
\hline \multirow[t]{2}{*}{ Marker } & \multirow{2}{*}{$\begin{array}{l}\text { No of } \\
\text { meiosex }\end{array}$} & \multicolumn{6}{|c|}{ Racombination fraction } \\
\hline & & 0.05 & 0.10 & 0.20 & 0.30 & 0.40 & \\
\hline \multirow[t]{3}{*}{ LDLR } & 30 & $-3 \cdot 70$ & $-2 \cdot 31$ & -0.95 & -0.35 & -0.07 & $m$ \\
\hline & 20 & 0.05 & 0.40 & 0.48 & 0.31 & 0.11 & f \\
\hline & & $-4 \cdot 40$ & $-2 \cdot 21$ & -0.68 & -0.06 & -0.004 & c \\
\hline \multirow[t]{3}{*}{$(3$} & 44 & -1.83 & -1.02 & -0.32 & -0.06 & 0.08 & $m$ \\
\hline & 37 & $-2 \cdot 20$ & $-1 \cdot 20$ & -0.42 & -0.11 & -0.03 & f \\
\hline & & 5.62 & -2.91 & -0.84 & -0.13 & -0.03 & c \\
\hline \multirow[t]{3}{*}{ APOC 2} & 53 & 0.12 & 0.28 & 0.30 & 0.19 & 0.04 & $m$ \\
\hline & 26 & -1.40 & -0.78 & -0.27 & -0.07 & -0.02 & f \\
\hline & & -3.22 & $-1 \cdot 40$ & -0.24 & 0.07 & 0.02 & c \\
\hline \multirow[t]{3}{*}{ D19S9 } & 21 & -0.66 & -0.15 & 0.18 & 0.15 & 0.06 & $m$ \\
\hline & 12 & -1.52 & -0.95 & -0.42 & -0.17 & -0.04 & f \\
\hline & & $-2 \cdot 18$ & $-1 \cdot 10$ & -0.24 & 0.02 & 0.02 & c \\
\hline \multirow[t]{3}{*}{ ( YPI } & 32 & 0.31 & 0.56 & 0.55 & 0.28 & 0.03 & $m$ \\
\hline & 24 & -2.40 & -1.62 & -0.69 & $-0 \cdot 23$ & -0.08 & f \\
\hline & & $-3 \cdot 10$ & $-1 \cdot 31$ & -0.11 & 0.16 & 0.06 & c \\
\hline \multirow[t]{3}{*}{ D19S6 } & 19 & -0.72 & -0.44 & -0.19 & -0.07 & -0.01 & $m$ \\
\hline & 24 & -0.55 & -0.28 & -0.08 & 0.00 & 0.00 & f \\
\hline & & -1.60 & -0.39 & -0.11 & -0.01 & 0.00 & c \\
\hline
\end{tabular}

$m=$ malc. $f=$ femalc. $c=$ combined.

Lod wores are calculated for:

Male's only $t_{1} m,\left\{\right.$ theta $a_{1} m_{1}$. theta $\left.a_{1} f_{1}=0.5\right\}$

Females only $i_{1,}\left\{\right.$ theta $a_{(m)}=0 \cdot 5$. theta $\left.a_{1,}\right\}$

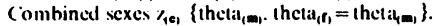




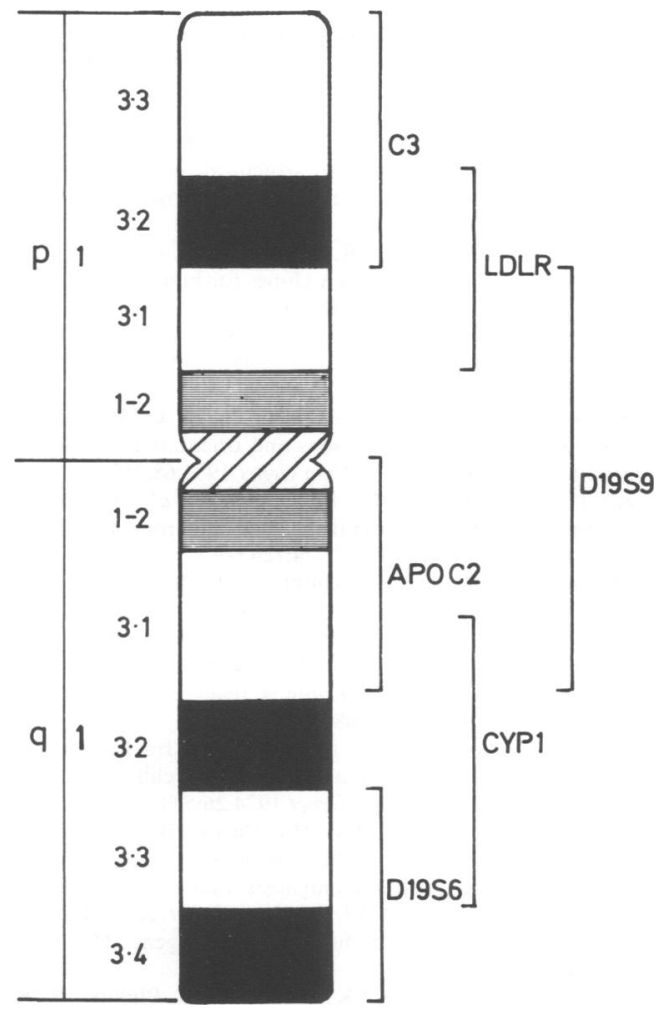

FiG 1 A phisical map of chromo.xome 19 showing the relatice positions of the markers used in this st udy.

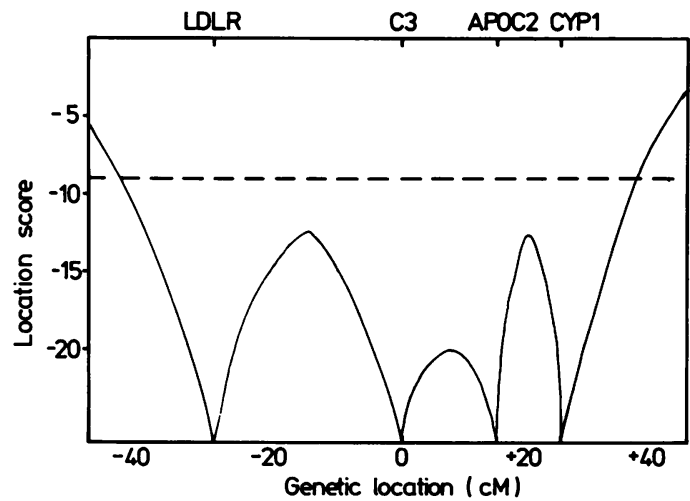

FIG 2 A likelihood map showing the location score for $C F$ at various map positions with respect to four fixed marker loci: LDLR. C3, APOC2, and CYP1. Genetic location is calculated with 3 at the arbitrary origin, that is, $w=0$ Morgans. Location scores $\left[1\left(w_{d}\right)\right]$ were calculated assuming equal male and female distances and the $L D L R-C 3$ dist ance $=30 \mathrm{CM}$, the $C 3-A P O C 2$ distance $=15 \mathrm{cM}$, and the APOC2-CYPI distance $=10 \mathrm{cM}^{29}{ }^{32}$ The broken line indicates a lod -2 exclusion limit. excluded genetic length derived from pairwise analyses is $102 \mathrm{cM}$. This is calculated by doubling the exclusion region around each locus and summing the individual regions.

\section{Discussion}

By analysing the segregation of cystic fibrosis with informative polymorphic DNA markers we have excluded $C F$ from a major proportion of chromosome 19. This has been achieved by the use of a fixed genetic map and multipoint analysis. The total exclusion limits achieved by multilocus analysis may be compared to that calculated by adding the exclusion limits derived from pairwise scores at each locus. For these data pairwise methods appear to exclude a larger area. However, adding pairwise scores is only valid if the scores for each pair of loci are independent. The data presented here are not independent; the same meioses contribute to several lod tables. Hence, multipoint analysis, which allows correctly for the interdependence of data at several loci, is the only valid method for estimating the total exclusion region for this data set. We note that the confidence for exclusion between markers using multipoint analysis is substantial, an example of the increase in information derived from each family when multipoint methods are used.

In the case of many autosomal recessive disorders of unknown biochemical aetiology, the search for a linkage is made more difficult by the absence of a reliable heterozygote detection system, thereby reducing the statistical power of each disease family; in general, only the parents and affected sibs contribute significantly to the lod score. In such circumstances a 'random' probe approach is less powerful than a structured approach, which involves the construction of genetic maps followed by the systematic exclusion of a disease locus from all points between a set of markers. This becomes particularly important if there is reason to suspect genetic heterogeneity.

The chromosomal location of $C F$ is now known and therefore this paper is not relevant to exclusion mapping for the $C F$ locus. However, it illustrates the power of LINKAGE in increasing the exclusion length using ordered markers on a single chromosome, and provides a model for this approach to an autosomal recessive disease. This model will be useful for the analysis of rare recessive diseases where the maximal information for linkage may be derived from the few families available for testing.

We wish to thank the many clinicians and families who have made this work possible by their enthusiasm and cooperation, Drs Bartlett, Fey, Humphries, 
Russell, Shaw, and Shepherd for the use of their cloned gene probes, and Dr Peter Scambler for helpful discussions. This work was supported generously by the UK Cystic Fibrosis Research Trust and the Medical Research Council. MF is a Foulkes Foundation fellow.

\section{References}

1 Quinton PM, Bijman J. Higher bioelectric potentials due to decreased chloride absorption in the sweat glands of patients with cystic fibrosis: $N$ Engl J Med 1983;308:1185-9.

2 Knowles M, Gatzy J, Boucher P. Increased bioelectric potential difference across respiratory epithelia in cystic fibrosis. $N$ Engl J Med 1981:305:1489-95.

3 Romeo G, Bianco M, Devoto M, et al. Incidence in Italy, genetic heterogeneity and segregation analysis of cystic fibrosis. Am J Hum Genet 1985;37:338-4.

4 Davies KE, Pearson PL, Harper PS, et al. Linkage analysis of two cloned DNA sequences flanking the Duchenne muscular dystrophy locus on the short arm of the human X chromosome. Nucleic Acids Res 1983;8:2303-12.

5 Gusella JF, Wexler NS, Conneally PM, et al. A polymorphic DNA marker genetically linked to Huntington's disease. Nature 1983;306:234-8.

- Mayo BJ, Lebe RJ, Barnett DR, Lankford BJ, Bowman BH. Somatic cell genetic studies of the cystic fibrosis mucociliary inhibitor. Clin Genet 1980;18:379-86.

7 Scambler P, Robbins T. Gilliam C, et al. Linkage studies between polymorphic markers on chromosome 4 and cystic fibrosis. Hum Genet 1985:69:250-4.

* Smith DW, Docter JM, Ferrier PE. Frias JL, Spock A. Possible localisation of the gene for cystic fibrosis of the pancreas to the short arm of chromosome 5. Lancet 1968;i:309-12.

- Edwards JH. Jonasson JA. Blackwell NL. Locus for cystic fibrosis. L ancet 1984:i:1020.

10 Scambler PJ, Wainwright BJ, MacGillivray TA, Fung M, Williamson R. Exclusion of human chromosome $13 q 34$ as the site of the cystic fibrosis mutation. Am J Hum Genet (in press).

"Scambler PJ, Williamson R. The structural gene for human coagulation factor $X$ is located on chromosome 13q34. Cytogenet Cell Genet 1985:39:231-3.

12 Davies KE, Gilliam TC, Williamson R. Cystic fibrosis is not caused by a defect in the gene coding for human complement C3. Mol Biol Med 1983:1:185-90.

13 Eiberg J, Mohr J, Schmiegelow K. Nielson LS, Williamson R. Linkage relationships of paraoxonase (PON) with other markers: indication of PON-cystic fibrosis synteny. Clin Genet 1985;28:265-71.

14 Wainwright BJ, Scambler PJ, Schmidtke J, et al. Localization of cystic fibrosis locus to human chromosome 7cen-q22. Nature 1985:318:384-5.

15 Scambler PJ, Wainwright BJ, Farrall M, et al. Linkage of Col 1A2 collagen gene to cystic fibrosis, and its clinical implications. Lancet 1985;ii: 1241 .
16 White R, Woodward S, Leppert M, et al. A closely linked genetic marker for cystic fibrosis. Nature 1985;318:382-4.

17 Tsui LC, Buchwald M, Barker D, et al. Genetically linked polymorphic DNA marker. Science 1985;230:1054-7.

18 Whitehead AS, Solomon E, Chambers S, Bodmer WF, Povey S, Fey G. Assignment of the structural gene for the third component of human complement to chromosome 19. Proc Nat Acad Sci USA 1982:79:5021-5.

19 Myklebost O, Williamson R, Markham AF, et al. The isolation and characterisation of cDNA clones for human apolipoprotein CII. J Biol Chem 1984;259:4401-4.

20 Phillips IR, Shephard EA, Ashworth A, Rabin R. Isolation and sequence of a human cytochrome P-450 cDNA clone. Proc Nat Acad Sci USA 1985; 82:983-7.

"1 Brook JD, Shaw DJ, Meredith L, Bruns GAP, Harper PS. Localisation of genetic markers and orientation of the linkage group on chromosome 19. Hum Genet 1984;68:282-5.

22 Kunkel LM, Smith DK, Boyer SH, et al. Analysis of $\mathrm{Y}$ chromosome specific reiterated DNA in chromosome variants. Proc Natl Acad Sci USA 1977;74:1245-9.

23 Maniatis T, Fritsch EF, Sambrook J. Molecular cloning: a laboratory manual. New York: Cold Spring Harbor Press, 1982.

24 Gilliam TC, Scambler P, Robbins T, Ingle C, Williamson R, Davies KE. The positions of three restriction fragment length polymorphisms on chromosome 4 relative to known genetic markers. Hum Genet 1984;68:154-8.

is Ott J. Estimation of the recombination fraction in human pedigrees: efficient computation of the likelihood for human linkage studies. Am J Hum Genet 1974;26:588-97.

26 Humphries SE, Kessling AM, Horsthemke B, et al. A common DNA polymorphism of the low-density lipoprotein (LDL) receptor gene and its use in diagnosis. Lancet 1985;ii:1003-5.

27 Humphries SE, Jowlett NI, Williams L, et al. A DNA poly morphism adjacent to the human apo CII gene. Mol Biol Med. 1983;1:463-71.

28 Wainwright BJ, Watson EK, Shephard EA, Phillips IR. RFLP for a human cytochrome P-450 gene at 19q13.1-qter (HGM8 provisional designation CYPI). Nucleic Acids Res 1985;13:4610.

29 Wainwright BJ, Lench NJ, Watson EK, et al. Linkage studies on chromosome 19. Cytogenet Cell Genet 1985;40:772.

30 Lathrop GM, Lalouel JM, Julier C, Ott J. Strategies for multilocus linkage analysis in humans. Proc Natl Acad Sci USA 1984;81:3443-6.

31 Farrall M, Scambler P, North P, Williamson R. The analysis of multiple polymorphic loci on a single human chromosome to exclude linkage to inherited disease: cystic fibrosis and chromosome 4. Am J Hum Genet 1986;38:75-83.

32 Sherman SL, Ball ST, Robson EB. A genetic map of chromosome 19 based on 2-point lod tables. Cytogenet Cell Genet 1985:40:742.

Correspondence and requests for reprints to Professor $\mathrm{R}$ Williamson, Department of Biochemistry, St Mary's Hospital Medical School, London W2 1PG. 